\title{
THE OXIDATION OF $\mathrm{NO}_{2}$ TO NITRATE- DAY AND NIGHT
}

In a recent article Richards (1983) has suggested a chemical reaction mechanism, given in Table 1 , for night-time $\mathrm{NO}_{2}$ oxidation. Richards makes several qualitative statements concerning the ability of this mechanism to represent measured night-time $\mathrm{NO}_{x}$ concentrations but does not present simulated results based on this mechanism. In order to assess the validity of Richards' suggested mechanism, we have integrated the rate equations corresponding to the reactions in Table 1 under the following conditions: (1) There is a constant source of NO, $S_{\mathrm{NO}}\left(\mathrm{ppm} \mathrm{min}^{-1}\right)$ during the night, (2) At $t=0$ (1800 PDT) the initial concentrations are those reported by Platt $e t$ al. (1980) from the Los Angeles area. These initial conditions are summarized in Table 2. Since the NO concentration at 1800 PDT was not reported by Platt et al. (1980), to obtain an initial condition we have assumed that the concentration of NO at this time can be obtained from the $\mathrm{NO}_{2}$ and $\mathrm{O}_{3}$ concentrations through the photostationary state relation with an approximate $\mathrm{NO}_{2}$ photolysis rate of $0.1 \mathrm{~min}^{-1}$. The NO emission flux, $\mathrm{S}_{\mathrm{NO}}$, must be specified to carry out the calculation, and we have considered values typical for Los Angeles. The object of our calculation is, as we noted above, to ascertain if the reaction set in Table 1 is capable of explaining observed night-time $\mathrm{NO}_{x}$ chemistry.

Based on the reactions in Table 1 , we can suggest the behavior of night-time $\mathrm{NO}_{x}$ chemistry. First, assuming no 
Table 1. Proposed mechanism for night-time $\mathrm{NO}_{x}$ chemistry (Richards, 1983)

\begin{tabular}{|c|c|c|}
\hline & Reaction & $\begin{array}{c}\mathbf{k} @ 298 \mathrm{~K} \\
\text { ppm-min units }\end{array}$ \\
\hline $\begin{array}{l}(1) \\
(2)\end{array}$ & $\begin{array}{l}\mathrm{NO}+\mathrm{O}_{3} \rightarrow \mathrm{NO}_{2}+\mathrm{O}_{2} \\
\mathrm{NO}_{2}+\mathrm{O}_{3} \rightarrow \mathrm{NO}_{3}+\mathrm{O}_{2}\end{array}$ & $\begin{array}{l}24 \\
0.050\end{array}$ \\
\hline (3) & $\mathrm{NO}_{3}+\mathrm{NO}_{2} \stackrel{\mathrm{M}}{\rightarrow} \mathrm{N}_{2} \mathrm{O}_{5}$ & 3900 \\
\hline $\begin{array}{l}\text { (4) } \\
\text { (5) }\end{array}$ & $\begin{array}{l}\mathrm{N}_{2} \mathrm{O}_{5} \stackrel{\mathrm{M}}{\rightarrow} \mathrm{NO}_{3}+\mathrm{NO}_{2} \\
\mathrm{~N}_{2} \mathrm{O}_{3}+\mathrm{H}_{2} \mathrm{O} \rightarrow 2 \mathrm{HNO}_{3}\end{array}$ & $\begin{array}{l}7.02 \min ^{-1} \\
<3 \times 10^{-6}\end{array}$ \\
\hline $\begin{array}{l}(6)^{*} \\
(7) \\
(8)\end{array}$ & $\begin{array}{l}\mathrm{N}_{2} \mathrm{O}_{5}+\mathrm{H}_{2} \mathrm{O} \text { surface } \\
\mathrm{NO}_{2}+\mathrm{NO}_{3} \rightarrow \mathrm{NO}_{2}+\mathrm{NO}+\mathrm{O}_{2} \\
2 \mathrm{NO}_{3} \rightarrow 2 \mathrm{NO}_{2}+\mathrm{O}_{2}\end{array}$ & $\begin{array}{l}0.84 \\
0.34\end{array}$ \\
\hline $\begin{array}{l}(9)^{*} \\
(10) \\
(11)\end{array}$ & $\begin{array}{l}\mathrm{NO}_{3} \stackrel{\text { surface }}{\longrightarrow} \mathrm{NO}_{2}+\frac{1}{2} \mathrm{O}_{2} \\
\mathrm{NO}_{3}+\mathrm{NO} \rightarrow 2 \mathrm{NO}_{2} \\
\mathrm{NH}_{4} \mathrm{NO}_{3}(\mathrm{~s}) \rightleftharpoons \mathrm{HNO}_{3}+\mathrm{NH}_{3}\end{array}$ & $\begin{array}{l}28000 \\
K_{\text {eq }}=5 \times 10^{-5} \mathrm{ppm}^{2}\end{array}$ \\
\hline
\end{tabular}

* Rate constants estimated using simple hard-sphere kinetic theory.

Table 2. Assumed initial conditions for night-time $\mathrm{NO}_{x}$ chemistry

\begin{tabular}{lcl}
\hline Species & \multicolumn{1}{c}{ Initial } \\
concentration (ppm)
\end{tabular}

* The source rate of injection of NO, $\mathrm{S}_{\mathrm{NO}}$ was estimated as the order of $10^{-3} \mathrm{ppm} \mathrm{min}^{-1}$ in the Los Angeles area.

†The source rate of injection of $\mathrm{NH}_{3}$ was estimated as $8.3 \times 10^{-6} \mathrm{ppm}$ $\min ^{-1}$ in the Los Angeles area.

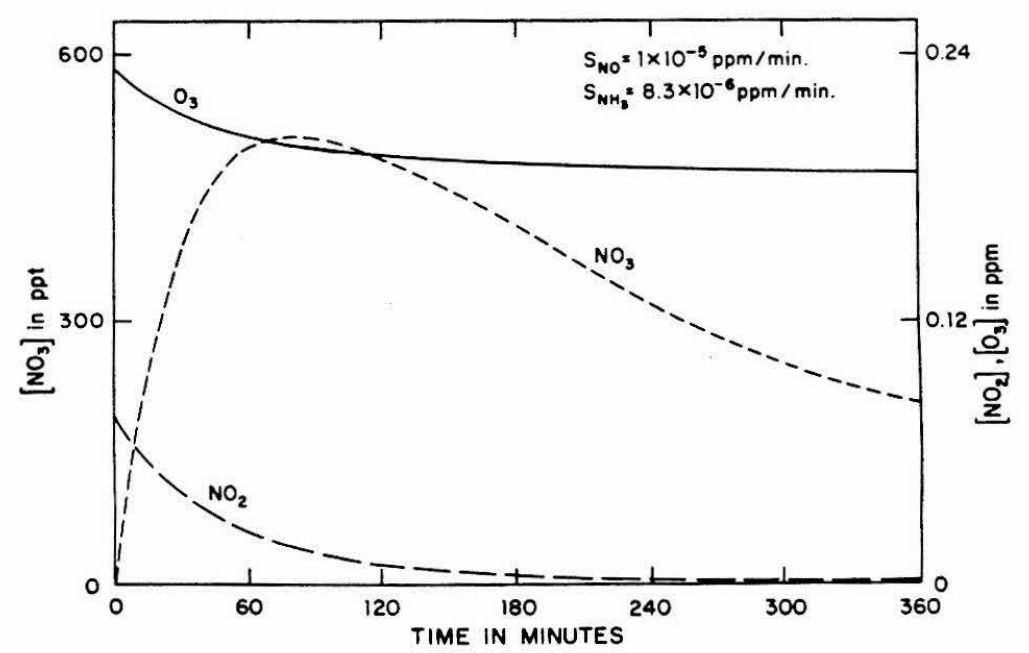

Fig. 1. Night-time $\mathrm{NO}_{3}, \mathrm{NO}_{2}$ and $\mathrm{O}_{3}$ concentrations as predicted by the mechanısm in Table 1 with $\mathrm{S}_{\mathrm{NO}}=10^{-5} \mathrm{ppm} \mathrm{min}{ }^{-1}$ and $\mathrm{S}_{\mathrm{NH}_{3}}=8.3 \times 10^{-6} \mathrm{ppm} \mathrm{min}{ }^{-1}$ and with $k_{5}$

$$
=3 \times 10^{-6} \mathrm{ppm}^{-1} \mathrm{~min}^{-1} \text {. }
$$


replenishment from the upper atmosphere, the $\mathrm{O}_{3}$ present at sunset will be continually removed by reaction with both NO and $\mathrm{NO}_{2}$, so we expect a declining $\mathrm{O}_{3}$ concentration. $\mathrm{NO}$ is initially depleted by reaction with $\mathrm{O}_{3}$ faster than it is replenished by the source flux, $\mathrm{S}_{\mathrm{NO}}$. If $\mathrm{S}_{\mathrm{NO}}$ is sufficiently large, when the rate of influx of NO from sources exceeds that of removal by reaction with $\mathrm{O}_{3}$ and $\mathrm{NO}_{3}$, especially when $\mathrm{O}_{3}$ has been substantially depleted, the NO concentration will begin to increase. Platt's data (1980) indicate a slight increase in the NO concentration as the night progresses. $\mathrm{NO}_{2}$ may initially decrease or increase depending on the relative amounts of $\mathrm{NO}$ and $\mathrm{O}_{3}$. Finally, $\mathrm{NO}_{3}$ is expected to increase after sunset due to the $\mathrm{NO}_{2}-\mathrm{O}_{3}$ reaction but reach a maximum and decrease as $\mathrm{O}_{3}$ is consumed.

Figures 1 and 2 show the predicted concentrations of $\mathrm{NO}_{3}$, $\mathrm{NO}_{2}, \mathrm{O}_{3}$ and $\mathrm{NO}$ over the period 1800 to 2400 PDT for $\mathrm{S}_{\mathrm{NO}}$ $=10^{-5}$ and $10^{-3} \mathrm{ppm} \mathrm{min} \mathrm{mo}^{-1}$ NO injection rates. At the lower $\mathrm{NO}$ source rate, $\mathrm{NO}_{3}$ and $\mathrm{O}_{3}$ persist longer, and the $\mathrm{NO}_{2}$ concentration falls to zero within 4 hs. On the other hand, with a higher $\mathrm{NO}$ source rate, the $\mathrm{NO}_{3}$ and $\mathrm{O}_{3}$ concentrations reach zero in $3 \mathrm{hs}$, and the $\mathrm{NO}_{2}$ concentration, after a small initial drop due to reaction with $\mathrm{O}_{3}$, rises and levels out. In both cases, the equilibrium $\mathrm{HNO}_{3}$ and $\mathrm{NH}_{3}$ concentrations are unaffected by the value of $\mathrm{S}_{\mathrm{NO}}$. A change in the $\mathrm{NH}_{3}$ source rate was found to have virtually no effect on the predicted concentration profiles for the gaseous species.

Night-time $\mathrm{NO}_{3}$ concentrations in Los Angeles have been reported by Platt et al. (1980) as noted above. The maximum $\mathrm{NO}_{3}$ concentration reported was $\sim 300$ ppt at 2000 PDT on 12 September 1979. By 2400 PDT, the $\mathrm{NO}_{3}$ concentration had fallen markedly. This observed maximum $\mathrm{NO}_{3}$ concentration is of the same order of magnitude as that predicted by the mechanism in Table 1. On less polluted days, the reported $\mathrm{NO}_{3}$ concentrations of $10-40 \mathrm{ppt}$ are an order of magnitude smaller than predicted. The $\mathrm{O}_{3}$ and $\mathrm{NO}_{2}$ concentrations predicted by the mechanism display the correct behavior and are of the correct order of magnitude at the higher $\mathrm{S}_{\mathrm{NO}}$ value of $10^{-3} \mathrm{ppm} \mathrm{min}^{-1}$.

In addition to the variable $\mathrm{NO}$ and $\mathrm{NH}_{3}$ source strengths,

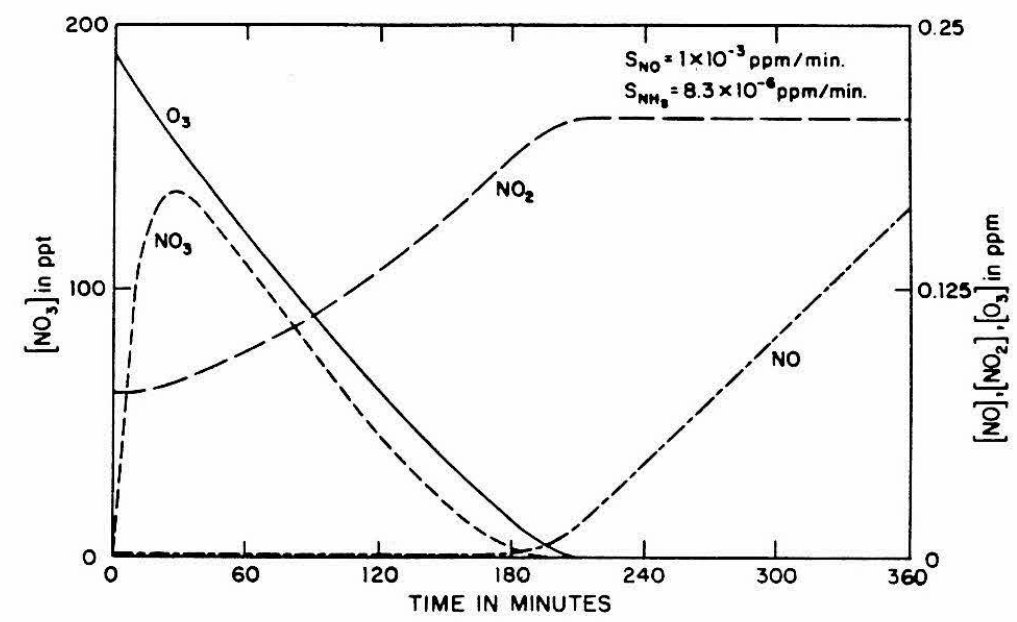

Fig. 2. Night-time $\mathrm{NO}_{3}, \mathrm{NO}_{2}$ and $\mathrm{O}_{3}$ concentrations as predicted by the mechanisms in Table 1 with $\mathrm{S}_{\mathrm{NO}}=10^{-3} \mathrm{ppm} \mathrm{min}^{-1}$ and $\mathrm{S}_{\mathrm{NH}_{3}}=8.3 \times 10^{-6} \mathrm{ppm} \mathrm{min}^{-1}$ and with $k_{5}=3 \times 10^{-6} \mathrm{ppm}^{-\mathrm{T}^{3}} \mathrm{~min}^{-1}$.

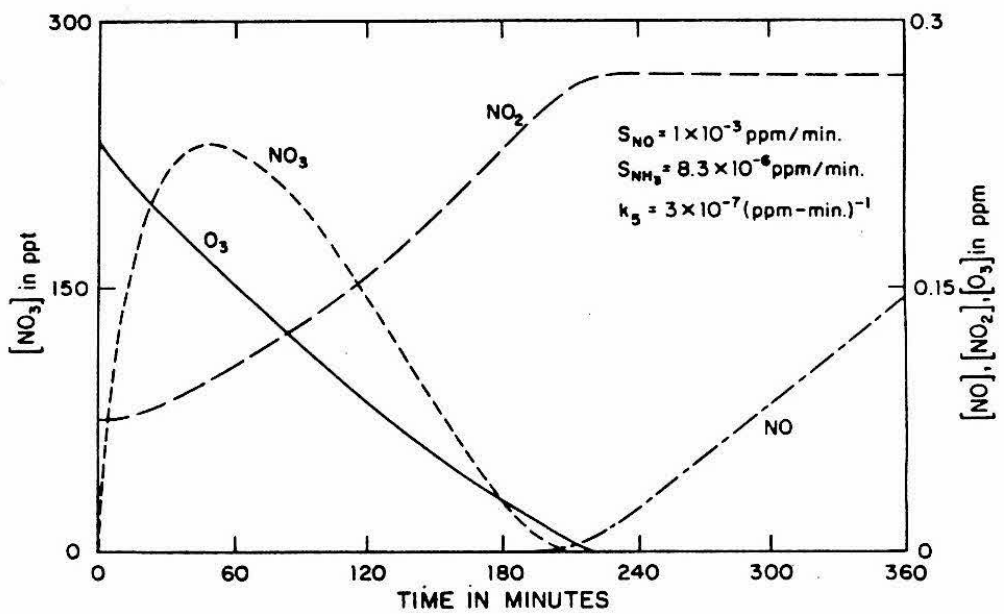

Fig. 3. Night-time $\mathrm{NO}_{3}, \mathrm{NO}_{2}$ and $\mathrm{O}_{3}$ concentrations as predicted by the mechanism in Table 1 with $\mathrm{S}_{\mathrm{NO}}=10^{-3} \mathrm{ppm} \mathrm{min}{ }^{-1}$ and $\mathrm{S}_{\mathrm{NH}_{3}}=8.3 \times 10^{-6} \mathrm{ppm} \mathrm{min}{ }^{-1}$ and with $k_{5}$ $=3 \times 10^{-7} \mathrm{ppm}^{-1} \mathrm{~min}^{-1}$ 


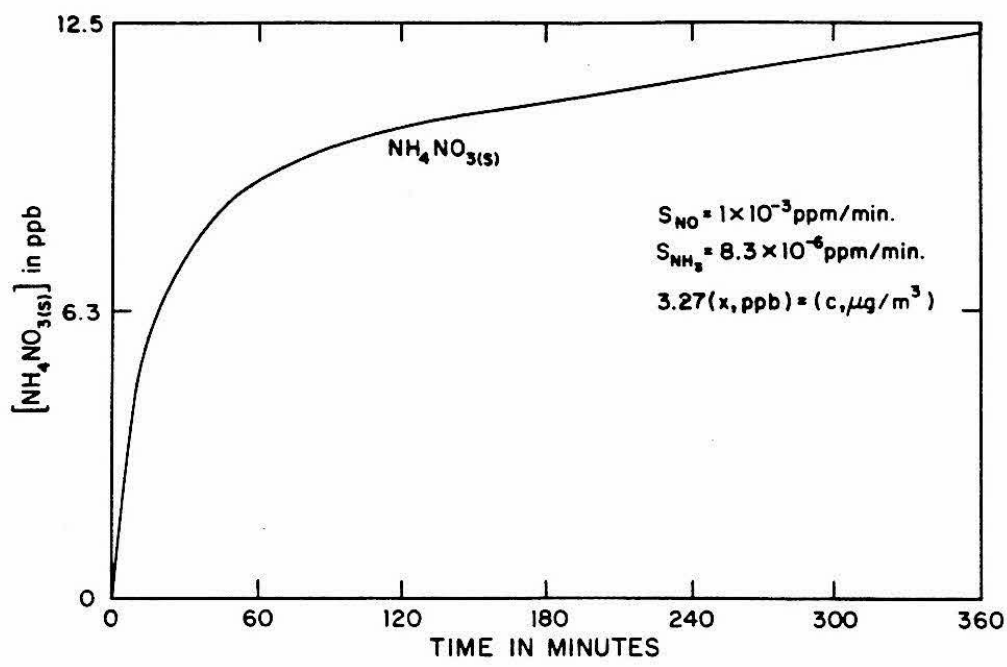

Fig. 4. Solid ammonium nitrate concentration predicted by the mechanism in Table 1 with $\mathrm{S}_{\mathrm{NO}}=10^{-3} \mathrm{ppm} \mathrm{min}{ }^{-1}$ and $\mathrm{S}_{\mathrm{NH}_{3}}=8.3 \times 10^{-6} \mathrm{ppm} \mathrm{min}{ }^{-1}$ and with $k_{5}=3$ $\times 10^{-6} \mathrm{ppm}^{-1} \mathrm{~min}^{-1}$.

the rate constants for reactions 5,6 and 9 of Table 1 are inaccurately known. Simple hard-sphere kinetic theory was used to approximate $k_{6}$ and $k_{9}$. A change in these values produced a negligible change in the profiles. On the other hand, reducing $k_{5}$ by an order of magnitude resulted in a dramatic change in the $\mathrm{NO}_{3}$ curve as can be seen in Fig. 3.

It is interesting to note that Richards states "It was observed in both cases that the concentration of $\mathrm{NO}_{3}$ during the night was less than (our emphasis added) predicted by the above set of reactions and rate constants". Our calculations indicate that this is dependent upon the NO source strength and the rate constants used.

The particulate nitrate concentrations predicted by the mechanism (Fig. 4) are slightly higher than those cited by Richards, ranging from 20 to $40 \mu \mathrm{g} \mathrm{m}^{-3}$ from 1800 to $2400 \mathrm{~h}$, while the measured values cited were constant at $\sim 10 \mu \mathrm{g}$ $\mathrm{m}^{-3}$. The predicted values do show an upward trend, and from 2400 to $0600 \mathrm{~h}$ the actual measurements increase from 10 to $20 \mu \mathrm{g} \mathrm{m}^{-3}$.

The mechanism predicts that the $\mathrm{NO}_{3}$ concentration peaks approximately one hour after sunset and then slowly declines, whereas the observed $\mathrm{NO}_{3}$ does not reach a maximum until about $2 \mathrm{~h}$ after the measurements started. One problem, of course, with performing such simulations is that sunset did not occur until $1900 \mathrm{~h}(60 \mathrm{~min})$ so some photolysis reactions are still proceeding in the first hour of the measurements. Accounting for a delayed sunset will affect the time of the $\mathrm{NO}_{3}$ peak. Although this mechanism does not include reactions with organic species (e.g. aldehydes) or coupled $\mathrm{HONO}$ and $\mathrm{NO}_{3}$ chemistry, the results are of the same order as the data of Platt et al. on smoggy days. It should be noted that the initial conditions we have assumed apply to ground level in a populated area. At night, the NO emitted during the day tends to remain near the surface, isolating much of the $\mathrm{O}_{3}$ and $\mathrm{NO}_{x}$ in the upper atmosphere. The results we have calculated are thus applicable only to a limited portion of the atmosphere. Current photochemical air pollution models simulate multiday episodes and therefore include night-time chemistry (McRae and Seinfeld, 1983). Because the behavior of $\mathrm{NO}_{3}$ is not central to the overall chemistry in these models, reasonable accuracy in simulating night-time chemistry can be maintained without a detailed understanding of $\mathrm{NO}_{3}$ chemistry.

In summary, we find that the mechanism in Table 1 suggested by Richards does predict the correct order of observed night-time $\mathrm{NO}_{3}$ concentrations. Richards' suggestion that the mechanism predicts $\mathrm{NO}_{3}$ concentrations in excess of those observed is dependent on the conditions used in the simulation; in fact, observed $\mathrm{NO}_{3}$ concentrations, as reported by Platt et al. (1980), can be in excess of those predicted.

Department of Chemical Engineering

CAROL L. Jones California Institute of

Technology

Pasadena, CA 91125, U.S.A.

\section{REFERENCES}

McRae G. J. and Seinfeld J. H. (1983) Development of a second-generation mathematical model for urban air pollution-II. Evaluation of model performance. Atmospheric Environment 17, 501-522.

Platt V., Perner D., Winer A. M., Harris G. W. and Pitts J. N., Jr. (1980) Detection of $\mathrm{NO}_{3}$ in the polluted troposphere by differential optical absorption. Geophys. Res. Lett. 7, 89-92.

Richards L. W. (1983) Comments on the oxidation of $\mathrm{NO}_{2}$ to nitrate-day and night. Atmospheric Environment 17, 397-402.

Russell A. G., McRae G. J. and Cass G. R. (1983) Mathematical modeling of the formation and transport of ammonium nitrate aerosol. Atmospheric Environment 17, 949-964. 